\title{
The Exercise of the Law and the Need to Update, before Pandemia Problems 2019
}

\section{Langurén EB*}

Professor of Law, La Ciénega University Center, Mexico

*Corresponding author: Eduardo Barajas Langurén, Doctor of Law from the Autonomous University of Nuevo León, with Master's degree in Justice Administration and Public Security, Lawyer, Full-time Professor of Researcher, at the University Center of La Ciénega, Mexico,

\section{Opinion}

\section{Introduction}

In today's times, it is necessary to think about updating for the modern professional exercise, using information technologies and strengthening in the future.

Therefore, one of the main subjects pending to strengthen public and private universities, is essential the training and updating of their teaching staff in the proper use and management of information technologies, it becomes necessary to work on the adequacy of training programs, Especially in Latin American universities, so they must leave in the past the few trainings that many of them give them not useful, nor of benefit in the legal learning process; therefore, it would be worth designing updates in the use of technologies only and exclusively for the legal area and the use of platforms, making the most of the technology.

It will also be necessary to update the curricula and programs of study where it is sought to give strengths also to the students, taking advantage of the need that some institutions and public organizations, like-wise, interrupted their normal work activities, which they saw that the student faces the future and be able to promote in this way, not only at the national, but international level, before the International Criminal Court or even in the Inter-American Court of Human Rights, just to mention some international bodies in which knowledge is necessary for international competences, where practical basic knowledge is granted just to mention a few, be notified by electronic means and impose themselves on the present, offer evidence, as well as, the relief of hearings in a virtual way, a recommendation can be made, it is proposed that these updates be made by legal professionals in legal investigation, forensic practice of litigation in their various specialties and teaching experience. It should be noted that at present professors from public and private universities in the country are properly trained in the use and management of technologies, so, well know how to turn on and use computer equipment, otherwise it will be a concern and subject pending to solve and guarantee quality in university education.

So I will mention other aspects that made clear the global health problem caused by the virus pandemic called covid-19, how in the procurement and administration of justice, in their various areas they were materially affected and paralyzed because information technologies are not used, due to different factors , fundamentally the insolicable technology used, computer equipment they use in institutions are obsolete and in poor condition, in addition, of having no internet service, poor training of staff and in the same way, the lack of public policies, that is, legislative work that provides for the proper use and application of technological means of primary need to carry out efficient work.

It will be very difficult to continue to hide the law student, as well as, from legal professionals, modern current terms such as "Legal Tech", which is already used by law firms in countries considered first world and that has transformed the dynamics of traditional legal firms.

\section{Modernity and the different Impacts on Professional Practice}

Faced with the need for the use of technologies that 
were gradually generated in the professional practice of law, but which the institutions themselves do not have service for their own work activities, much less can share with the community of lawyers who come daily to seek to settle legal conflicts, in the face of the effects of the pandemic by covid-19, another factor that became problematic is the poor quality of the Internet services offered by different companies, this under virtue, that in the face of the isolation that is required for the control and decrease of contagions had to be used more internet services, so there are more users using the services there is cyber traffic, a term that a server i have used from this new learning dynamic. Being the main cause that is already evident and that was exposed that we paid for contracted services that are not granted to us, which can become breach of contracts or even the commission of a crime such as fraud, etc., by virtue of paying for expensive and very poor quality internet services, (it would be worthwhile for specialists in the matter to review what we pay and what we receive, since this can be measured), or it would be worth checking the fiber optics to efficient and guarantee services.

This factor could well become an obstacle to having the long-awaited dream of cyber justice, online judgments, in litigate's office and within reach of society. Such as video hearings within judicial districts, talking about the common jurisdiction, or it could be between the federation and federal entities and even, in the case of complying with what is established by the National Code of Criminal Procedures, in relation to the international legal assistance in criminal matters, in order to be able to carry out declarations of persons, in international collaboration in the case of crimes that were committed in another country and that Mexico can collaborate, in order to carry out declarations of people and that translates into optimizing economic resources, times, etc.

It is worth noting and insisting on having internet services that guarantee these activities, which strengthens legal certainty, in close relation to legal certainty.

Faced with the need to use private offices or even house studies to be able to teach virtual class, in the process of isolation by the covid-19 pandemic, several factors were found that were evident is that of the various vendors who pass through the streets and is considered informal trade, it seems that there are no municipal authorities that perform operational for the review of the decibels allowed to announce the sale of their products, what that interrupts students' classes by these means, and even in colonies that still listen to music at high volume and that is still hearing pollution, confirming that an operative has never been performed inviting awareness of hearing pollution. Therefore, municipalities must apply to regulate these activities and also respect the respective public policies.
The above, it was not all during this pandemic process were found other fads that students used to not participate and even evade their responsibility of students as is the argument that the light went in their homes, or that the internet is failing them and they can no longer connect, that the video camera does not serve, so that the teacher does not have real images of what he does at the time of class which showed aspects of the student's attitude, so ethical aspects of well-based and applied training need to be strengthened.

It is very important to pay attention to the services offered to society by the prosecutors' offices of federal entities, as well as that of the Federation where various aspects such as that which have never been thought of how to bring services closer to society through technologies, although true, that some state prosecutors such as Mexico City's, receive complaints virtually only for non-serious crimes, the truth is that other prosecutors, nor they have even acquired stateof-the-art computer equipment, much less have trained their staff in the proper use and management of information technologies.

It cannot be mentioned that in the case of the councils of the judiciary of the federal entities, it seems that also, they have the opportunity to improve in the service of society, this pandemic also caused economic paralysis to the guild of law under, having stopped receiving lawsuits and that the terms and procedural deadlines will be interrupted, since only cases of an urgent nature were attended, it should be noted that what was cared for as the first term is the health, which becomes number one and essential, because without health it cannot be continued, which is why, they protected all the staff who perform in these roles, but also the guild of trial lawyers were directly affected in obtaining the financial livelihood for family support, so the procurement and administration of justice was paralyzed, leaving many economic losses and affectations.

This pandemic I believe will also be used by students undergraduate, master's and doctoral students, in the legal areas to carry out theses at different levels, studying the different impacts that were experienced and generated problems for social legal development and thus providing aspects of continuous improvement in the legal areas.

It showed the delay in labor or labor law, by virtue of the remote work already being carried out, that is, practiced, so it was a form used by large companies, but the truth was an impossible to ask that this modality of work be regulated in the Federal Labor Law itself, so, with the emergence of this pandemic of covid-19, is already a reality that is obligatory and because of the need to do the work other companies, even government institutions put it into practice, so distance work remains a pending subject for regulation and legal 
authorization with the respective reform of the Labor Law.

It is necessary to include and disseminate in legal education the modern and current ways of administering the law firms themselves, by virtue of the use of at least just over five years of legal education the "Legal Tech", eminently Anglo-Saxon that is nothing more than applying and using technology to the provision or marketing of legal services, is why many of us have been in favor of this happening for social benefit, to shorten distances, saving economic resources, polluting the environment less and thus the planet, contributing to climate change by dispatching and promoting from office, without having to go to institutions physically to carry out and present judicial procedures or promotions, etc., which consists in the lawyer using technology to perform using the tools of the Legal tech drawer, without a doubt that it is something that helps the professional as technology applied to services and their commercialization, stressing that it also helps the client to qualify the lawyer in the provision of his services, but that it has as its main characteristic the INMEDIATEZ, Mexican constitutional principle.

As, raised in the previous paragraph, it is necessary for undergraduate students to learn the forms of legal validation performed over the Internet.

During the health contingency of the academic legal community, the virtual methodology had to be adapted to save the semester in an impromptu way in many of the cases, which caused and revealed the inequality between students, who have financial resources and have a computer and even a good cell phone, payment of plan with internet services and even in their homes and those who have nothing of the above, which prevented them from connecting to receive their classes.

From this pandemic event by the covid-19 virus or coronavirus, it was confirmed that the didactics of the future will be digital didactics, although this will have to conform to the effectiveness of legal education by virtue, that some barriers are detected that influence this dynamic of the future as it is stated: That contact with the student, teacher is what gives life to legal teaching, as it is the time when the teacher looks into the eyes of the students, to dialogue, interact, discuss, argue the subject in analysis, not to mention that at present in legal education it focuses on the vision of orality, by virtue of orality already practicing in commercial, criminal, agricultural, labor matters and there is an intention that the other specialties should be intended to be in the oral form, listening to opinions that in this way there can be no transmission of knowledge.

\section{Conclusion}

The above would transform human relations, in relation to this novel practice of legal education, which in my opinion, equates what in decades past was used in updating or teaching by correspondence, by registered mail, courses or teaching in electrician technician or automotive mechanic, to name a few examples.

Digital platforms cannot, and should not change the life of the law student, they can be used as alternative and practical forms in certain subjects and legal specialties, but not permanently, if so, universities would become empty spaces, without students, perhaps without generating research, which is already very scarce in the legal teaching classrooms in public and private universities in the country.

From the above, it is stated that the community of lawyers has to renew, update or change professional activity, since we cannot stand still and see time pass, the legal transition that for compelling reasons, social pressure, need to solve social problems, stay up-to-date and provide services that clients require and ask for professional support, so the challenges of the future of advocacy in Mexico after this pandemic covid-19, will necessarily be updated or engaged in other work activity.

So the modern dynamics of law in Mexico, will be very similar to the services offered by UBER, or even Netflix, with an equal contracting of services on platforms, as the Mexican jurist, Miguel Carbonell, wrote in the universal of June 2, 2020, and even states that "It has never been so interesting and challenging to be a lawyer", I think I agree that in a short time we will see the services of law firms on platforms professional legal services, including legal firms with legal professionals from other countries, where Mexican lawyers will have to compete with foreign professionals, where legal services will have globalized competence.

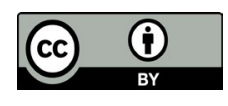

